\title{
CHI3L1 wt Allele
}

National Cancer Institute

\section{Source}

National Cancer Institute. CHI3L1 wt Allele. NCI Thesaurus. Code C125184.

Human CHI3L1 wild-type allele is located in the vicinity of $1 \mathrm{q} 32.1$ and is approximately 8 $\mathrm{kb}$ in length. This allele, which encodes chitinase-3-like protein 1, is involved in inflammation, chitin binding and tissue remodeling. Mutation of the gene is associated with increased susceptibility to asthma or schizophrenia. 